\title{
Ataxia-telangiectasia: linkage analysis in highly inbred Arab and Druze families and differentiation from an ataxia-microcephaly-cataract syndrome
}

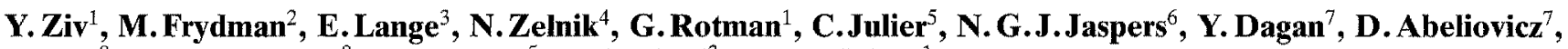 \\ H.Dar ${ }^{8}$, Z. Borochowitz ${ }^{8}$, M.Lathrop ${ }^{5}$, R.A. Gatti ${ }^{3}$, and Y. Shiloh ${ }^{1}$ \\ ${ }^{1}$ Department of Human Genetics, Sackler School of Medicine, Tel Aviv University, Ramat Aviv 69978, Israel \\ ${ }^{2}$ Department of Pediatrics, Hasharon Hospital, Petach-Tikva, Israel \\ ${ }^{3}$ Department of Pathology, UCLA School of Medicine, Los Angeles, CA 90024, USA \\ ${ }^{4}$ Department of Pediatrics and Pediatric Research Unit, Carmel Hospital, Technion Faculty of Medicine, Haifa, Israel \\ ${ }^{5}$ Centre d'Etude du Polymorphisme Humain, 27, Rue Juliette Dodu, F-75010 Paris, France \\ ${ }^{6}$ Laboratory of Cell Biology and Genetics, Erasmus University, NL-3000 DR Rotterdam, The Netherlands \\ ${ }^{7}$ Department of Human Genetics, Hadassah-Hebrew University Medical Center, Jerusalem, Israel \\ ${ }^{8}$ Simon Winter Center for Human Genetics, Bnai-Zion Medical Center, Technion Faculty of Medicine, P.O. Box 4940, Haifa, Israel
}

Received May 5, 1991

Summary. Ataxia-telangiectasia $(\mathrm{A}-\mathrm{T})$ is a progressive autosomal recessive disease featuring neurodegeneration, immunodeficiency, chromosomal instability, radiation sensitivity and a highly increased proneness to cancer. A-T is ethnically widespread and genetically heterogeneous, as indicated by the existence of four complementation groups in this disease. Several "A-T-like" genetic diseases share various clinical and cellular characteristics with A-T. By using linkage analysis to study North American and Turkish A-T families, the ATA (A-T, complementation group $\mathrm{A}$ ) gene has been mapped to chromosome 11q23. A number of Israeli Arab A-T patients coming from large, highly inbred families were assigned to group A. In one of these families, an additional autosomal recessive disease was identified, characterized by ataxia, hypotonia, microcephaly and bilateral congenital cataracts. In two patients with this syndrome, normal levels of serum immunoglobulins and alpha-fetoprotein, chromosomal stability in peripheral blood lymphocytes and skin fibroblasts, and normal cellular response to treatments with X-rays and the radiomimetic drug neocarzinostatin indicated that this disease does not share, with A-T, any additional features other than ataxia. These tests also showed that another patient in this family, who is also mentally retarded, is affected with both disorders. This conclusion was further supported by linkage analysis with 11q23 markers. Lod scores between A-T and these markers, cumulated over three large Arab families, were significant and confirmed the localization of the ATA gene to 11q23. However, another Druze family unassigned to a specific complementation group, showed several recombinants between

Offprint requests to: Y. Shiloh
A-T and the same markers, leaving the localization of the A-T gene in this family open.

\section{Introduction}

Ataxia-telangiectasia (A-T) is an autosomal recessive disease expressed as cerebellar degeneration, telangiectasia, immune deficiency, chromosomal instability, increased tendency to lymphoreticular malignancies, and radiosensitivity (Boder 1985; Cohen and Levy 1989; McKinnon 1987). Cultured A-T cells show elevated chromosomal breakage and rearrangements, increased sensitivity to ionizing radiation and radiomimetic chemicals, and a decreased inhibition of DNA synthesis after treatment with these agents (McKinnon 1987; Shiloh et al. 1985; Taylor 1982). To a limited extent, A-T heterozygotes also show a proneness to cancer and cellular hypersensitivity to the same DNA damaging agents (Arlett and Priestley 1985; Morrell et al. 1986; Paterson et al. 1985; Shiloh et al. 1983; Swift 1985).

A-T is ethnically widespread, with an average frequency of 1:40000 live births in Caucasian populations (Spector et al. 1982; Swift et al. 1986). Genetic heterogeneity in A-T is indicated by the existence of 4 complementation groups $(A, C, D$, and $E$ ), defined by in vitro studies (Jaspers et al. 1988a). In addition, a number of genetic syndromes display some of the clinical and cellular characteristics of A-T, usually with additional features (Curry et al. 1989; Fiorilli et al. 1985; Jaspers et al. 1988b; Seemanová 1990; Taalman et al. 1989; Taylor et al. 1987; Ziv et al. 1989). The relationship between A-T und these "A-T like" syndromes is not clear. 
Linkage studies recently led to the assignment of two A-T genes, ATA (A-T, group A) and ATC (A-T, group C), to the chromosomal region 11q23 (Gatti et al. 1988; McConville et al. 1990a, b; Sanal et al. 1990; Ziv et al. 1991). These results are expected to help to clarify the genetic and molecular basis of A-T and the "A-T-like" syndromes.

A-T has been found in Israel among Moroccan Jewish, Arab, Bedouin and Druze families. Complementation studies assigned several Moroccan Jewish pedigrees to group C and Arab pedigress to group A (Jaspers et al. 1988 and unpublished results). Bedouin and Druze families have not yet been assigned. The Arab A-T pedigrees are large and characterized by much inbreeding. In view of the ethnic distribution and genetic heterogeneity of A-T, we performed linkage analysis in Arabs and Druze, to confirm the localization of the A-T locus to $11 \mathrm{q} 23$ in these ethnic groups. An additional autosomal recessive disease was identified in one of the Arab families with A-T, involving ataxia, microcephaly and congenital cataract. We examine here the possible relationship between the two diseases, using a combination of linkage analysis and comparative studies of the immunologic, cytogenetic and cellular phenotypes of two types of patients in this family.

\section{Subjects and methods}

\section{Patients and families}

One Druze and three Arab A-T families were studied (Fig. 1). Initial diagnosis of A-T based on clinical examination was confirmed by measurements of serum immunoglobulins and alpha fetoprotein, cytogenetic analysis of peripheral blood lymphocytes and skin fibroblasts, and an assessment of the sensitivity of skin fibroblasts to ionizing radiation and the radiomimetic drug neoncarzinostatin (NCS). Six children in family ISAT9 (Fig. 1) had A-T. Three other children, VI-3, VI-4 and VI-14 (aged 3.7, 1.3 and 2.3 years, respectively, at the time of examination), showed a different disease, apparently inherited in an autosomal recessive manner and characterized by ataxia, hypotonia, microcephaly, bilateral congenital cataracts and searching nystagmus. Patient VI-3 also had bluish irises and moderate psychomotor retardation. Patients VI-4 and VI-14 were of normal intelligence. No telangiectases were observed.

\section{Cell cultures}

Primary fibroblast cell lines were established from skin biopsies obtained following informed consent; they were grown in Dulbecco's modified Eagle medium with 10\% fetal bovine serum (Beit Ha'Emek, Israel).

\section{Cytogenetic analysis}

Lymphocytes. Chromosome spreads were prepared from $0.1 \mathrm{ml}$ peripheral blood as described by Schwarzacher and Wolf (1974). Chromosomal damage was scored according to Cohen et al. (1967) and expressed as the number of chromatid breaks per cell. Structural rearrangements were considered to represent 2 chromatid breaks.

Fibroblasts. Monolayer cultures were split at a ratio of $1: 3$, and the cells were seeded onto coverslips, 2 days later. Colcemid was added to the cultures for $50 \mathrm{~min}$, the cells were collected and chromosome spreads were prepared. G-banding was performed according to Klinger (1987).

\section{Cellular sensitivity to DNA damaging agents}

Fibroblast monolayers at the late logarithmic phase were treated at $37^{\circ} \mathrm{C}$ for $20 \mathrm{~min}$ with various concentrations of NCS (Kayaku Antibiotics, Tokyo) in phosphate-buffered saline. The cultures were then trypsinized and replated at densities of $100-5000$ cells per $50 \mathrm{~mm}$ dish in order to assay their colony-forming ability.

\section{Inhibition of DNA synthesis by ionizing radiation}

Fibroblasts were plated in $30 \mathrm{~mm}$ dishes ( 70000 cells/dish). A day later, their DNA was prelabelled by adding ${ }^{14} \mathrm{C}$-thymidine $(50 \mathrm{mCi} /$ mmole; $0.03 \mu \mathrm{Ci} / \mathrm{ml}$ ), and incubation was continued for $16 \mathrm{~h}$. Following exposure to various doses of $\mathrm{X}$-rays, ${ }^{3} \mathrm{H}$-thymidine $(25 \mathrm{Cl} /$

Table 1. DNA probes and polymorphisms used in this study

\begin{tabular}{|c|c|c|c|c|c|}
\hline Locus & Probe & Enzyme & $\begin{array}{l}\text { Alleles } \\
\text { (kb) }\end{array}$ & $\begin{array}{l}\text { Allele } \\
\text { frequency }\end{array}$ & Source (reference) \\
\hline D11S84 & p2.71D6 & $\operatorname{TaqI}$ & $\begin{array}{l}6.4 \\
4.2\end{array}$ & $\begin{array}{l}0.24 \\
0.76\end{array}$ & M. Litt (Maslem et al. 1987) \\
\hline STMY & psp64 & $\operatorname{Taq} \mathrm{I}$ & $\begin{array}{l}4.6 \\
2.1,1.0\end{array}$ & $\begin{array}{l}0.52 \\
0.48\end{array}$ & N. K. Spurr (Spurr et al. 1988) \\
\hline D11S132 & CRI-L424 & HindIII & $\begin{array}{l}2.9 \\
1.9\end{array}$ & $\begin{array}{l}0.60 \\
0.40\end{array}$ & Collaborative Research, Inc. (Donis-Keller et al. 1987) \\
\hline D11S144 & pYNB3.12 & MspI & $\begin{array}{l}2.9 \\
2.6\end{array}$ & $\begin{array}{l}0.53 \\
0.47\end{array}$ & Y. Nakamura (Carlson et al. 1988) \\
\hline D11S351 & CJ52.208 & MspI & $\begin{array}{l}4.0 \\
3.2\end{array}$ & $\begin{array}{l}0.41 \\
0.59\end{array}$ & M. Lathrop (Julier et al. 1990) \\
\hline $\mathrm{CD} 3 \mathrm{G}$ & PT3dH & MspI & $\begin{array}{l}2.5 \\
1.7,0.8\end{array}$ & $\begin{array}{l}0.80 \\
0.20\end{array}$ & R. A. Gatti (Charmley et al. 1989) \\
\hline
\end{tabular}




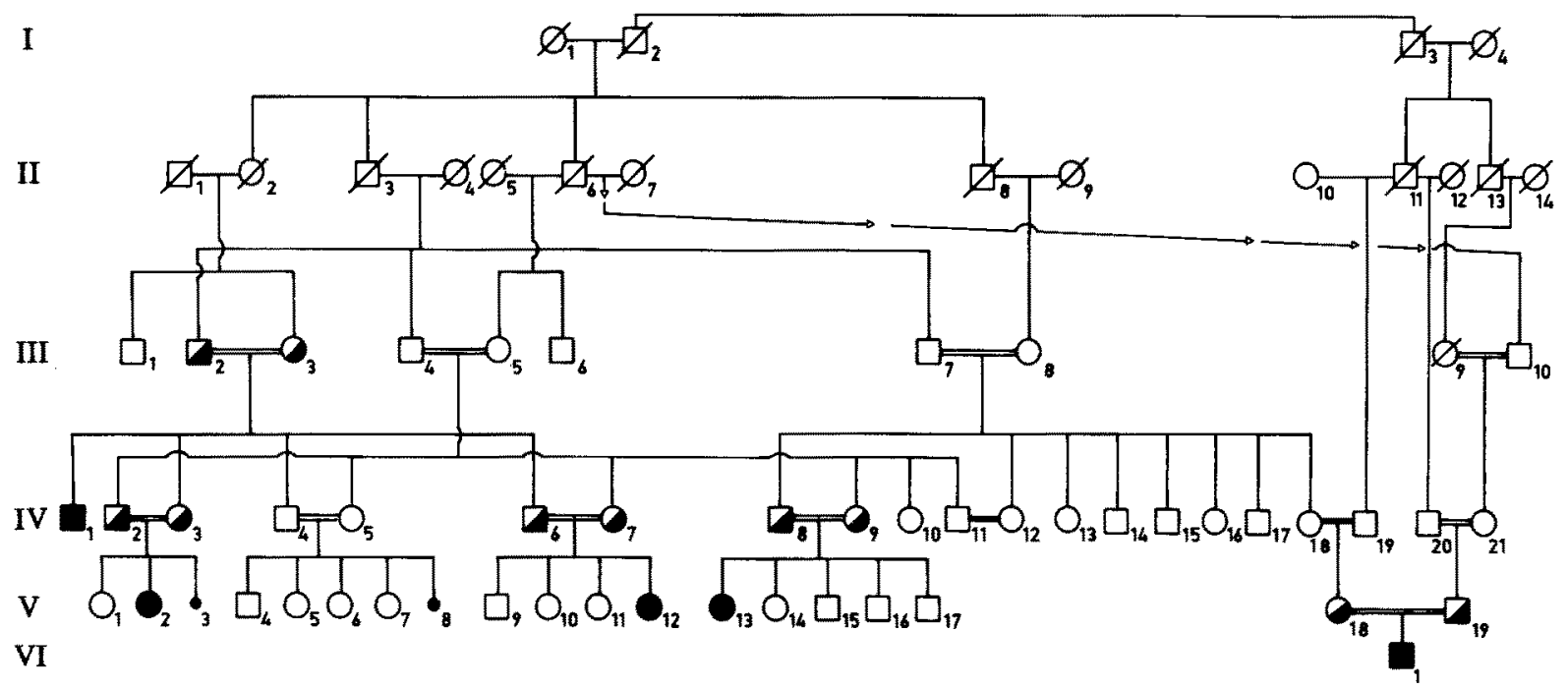

Family ISAT 3

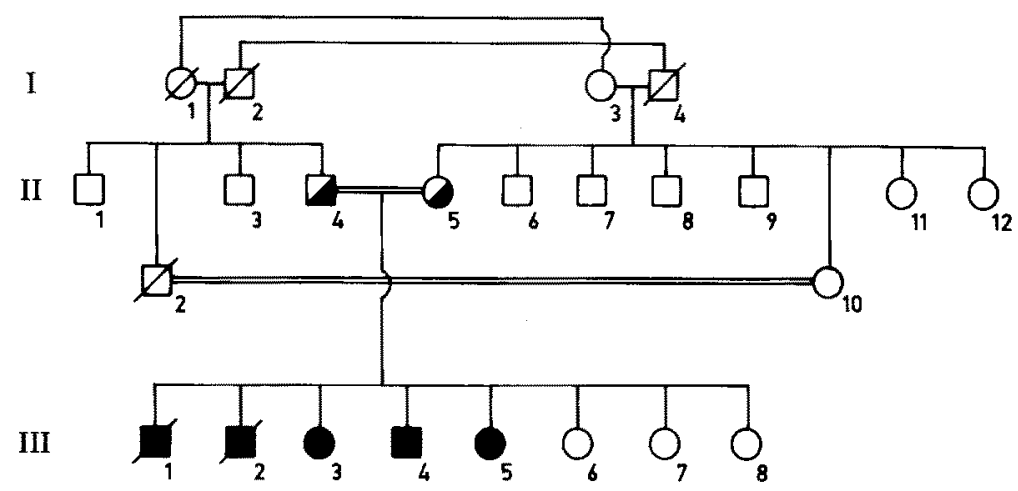

Family ISAT 9

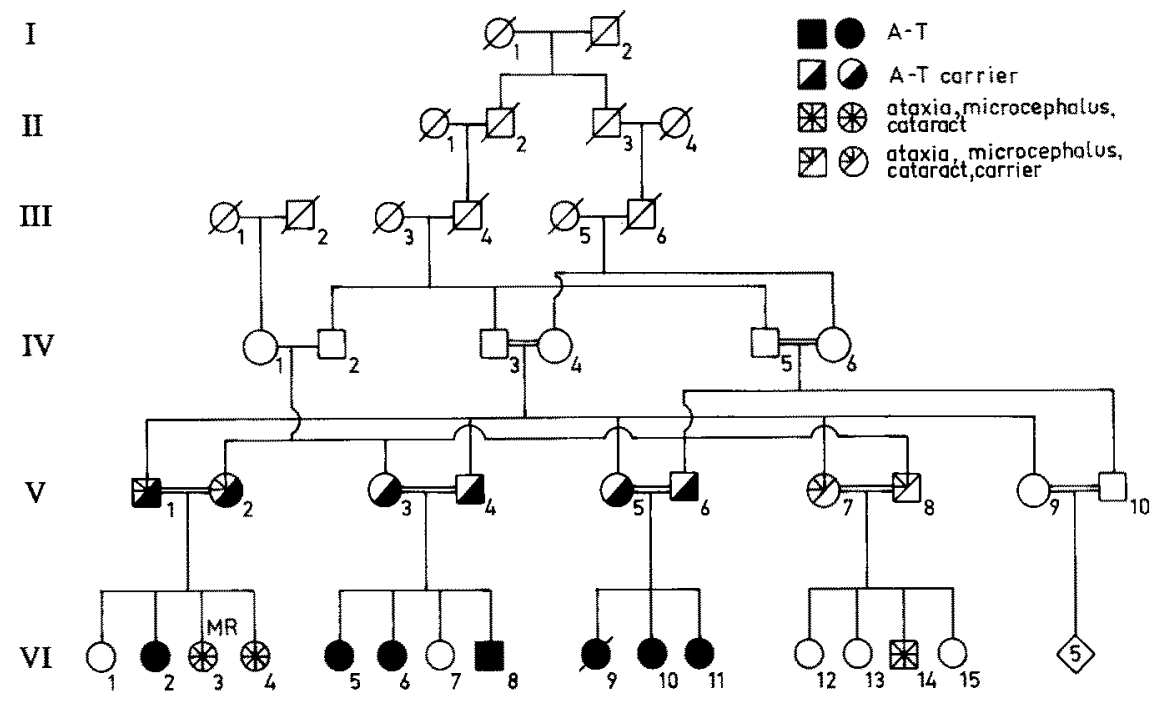

Family ISAT 8

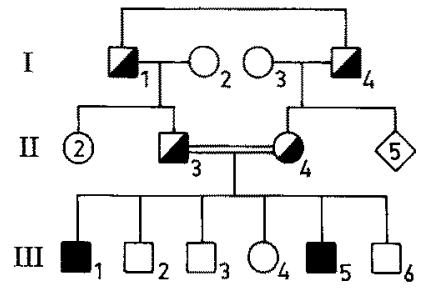

Fig. 1. Pedigrees of the families analyzed. Families ISAT1, ISAT3 and ISAT9 are Arab. Family ISAT8 is Druze. $\mathbf{D}$, A-T patients; $\mathbf{Z}, \bigcirc$ A-T heterozygotes

mmole; $2.5 \mu \mathrm{Ci} / \mathrm{ml}$ ) was added and incubation was continued at $37^{\circ} \mathrm{C}$ for $3 \mathrm{~h}$. The $\mathrm{pH}$ of the cultures was maintained at 7.4 throughout the labeling period by the presence of $20 \mathrm{mM}$ HEPES. The cells were harvested by scraping, and the ratio of ${ }^{3} \mathrm{H}$ to ${ }^{14} \mathrm{C}$ in trichloroacetic acid precipitates was used to measure the rate of DNA synthesis.

\section{Southern blotting}

DNA was isolated from fibroblast cultures according to standard methods (Sambrook et al. 1989), and cleaved with restriction endonuclease under the conditions recommended by the manufacturers. The fragments were separated by electrophoresis in $0.6 \%-$ 
$0.8 \%$ agarose gels and transferred to Nytran membranes (Schleicher and Schuell), according to Southern (1975). Probes (Table 1) were labeled by random priming (Feinberg and Vogelstein 1983). Hybridization and autoradiography were performed as described by Sakai et al. (1985).

\section{Linkage analysis}

All linkage calculations were performed by the pedigree analysis program MENDEL (Lange et al. 1988). This program is especially appropriate for large inbred pedigrees because of the efficient way in which it handles inbreeding (Lange and Boehnke 1983), and its systematic elimination of superfluous genotypes conducted internally prior to likelihood calculations (Lange and Goradia 1987).

\section{Results}

\section{Relationship between the two diseases in family ISAT9}

The two genetic diseases that segregate in this family (Fig. 1) apparently share a common feature, ataxia. It was of interest to determine whether they share additional phenotypic features, which would point to the possible identity of the genes that determine them. This was particularly important for linkage analysis in this family since, if both diseases are determined by genes residing at the same locus, a combined lod score should be greater than either of the two separate lod scores.

Table 2 summarizes the immunologic characterization of the A-T patient VI-2, and of those with ataxiamicrocephaly-cataract (AMC). The A-T patient showed a significant reduction in $\operatorname{IgA}$ and elevation of alphafetoprotein levels in her serum, both characteristic of A-

Table 2. Immunoglobulin and alpha-fetoprotein levels in the serum of various members of family ISAT9. MR, Mental retardation

\begin{tabular}{|c|c|c|c|c|c|}
\hline \multirow{2}{*}{$\begin{array}{l}\text { Sub- } \\
\text { ject }\end{array}$} & \multirow{2}{*}{$\begin{array}{l}\text { Clinical } \\
\text { phenotype }\end{array}$} & \multicolumn{3}{|c|}{ Immunoglobulins (mg/dl) } & \multirow{2}{*}{$\begin{array}{l}\text { Alpha- } \\
\text { feto- } \\
\text { protein } \\
\text { (ng/ml) }\end{array}$} \\
\hline & & $\operatorname{Ig} A$ & $\operatorname{IgG}$ & $\operatorname{IgM}$ & \\
\hline $\mathrm{VI}-2$ & $A-T$ & 7 & 1510 & 110 & 87 \\
\hline $\mathrm{VI}-3$ & $\mathrm{AMC}+\mathrm{MR}$ & 10 & 1225 & 145 & 40 \\
\hline $\mathrm{VI}-4$ & $\mathrm{AMC}$ & 45 & 980 & 90 & 8 \\
\hline$V I-14$ & $\mathrm{AMC}$ & 160 & 1800 & 90 & 6.5 \\
\hline \multicolumn{2}{|c|}{ Normal range: } & $25-140$ & $520-1450$ & $40-200$ & $2-20$ \\
\hline
\end{tabular}

Table 3. Chromosomal instability in cells from four members of family ISAT9. MR, Mental retardation

\begin{tabular}{llll}
\hline Subject & Clinical phenotype & \multicolumn{2}{c}{ Chromatide breaks/cell } \\
\cline { 3 - 4 } & & $\begin{array}{l}\text { Lympho- } \\
\text { cytes }\end{array}$ & $\begin{array}{l}\text { Fibro- } \\
\text { blasts }\end{array}$ \\
\hline VI-2 & A-T & 0.26 & 0.71 \\
VI-3 & AMC + MR & 0.30 & 0.63 \\
VI-4 & AMC & 0 & 0.03 \\
VI-14 & AMC & 0.01 & 0.02 \\
\hline
\end{tabular}

T. The three patients with AMC varied: VI-3 resembled her sister with A-T, whereas VI-4 and VI-14 showed normal values of alpha fetoprotein and immunoglobulins. The same was true when chromosomal stability was tested in their lymphocytes and fibroblasts (Table 3): again, both VI-2 and VI-3 showed an A-T phenotype, expressed as high chromosomal breakage, whereas VI-4 and VI-14 showed normal chromosomal stability.

Two additional features of the cellular A-T phenotype are increased sensitivity to the lethal action of ionizing radiation and radiomimetic chemicals, and decreased inhibition of DNA synthesis by these agents. Figure 2 shows the response of fibroblast cell lines from several affected individuals of the family to increasing doses of the radiomimetic drug NCS, as measured by their colony-forming ability. Whereas cells from VI-3 demonstrated an extreme hypersensitivity to NCS, like those of her sister with A-T (VI-2), the other two patients with AMC showed an intermediate response, typical of A-T heterozygotes (Shiloh et al. 1982, 1983). Finally, when the inhibition of DNA synthesis by X-rays was tested, VI-3 again showed a response that was indistinguishable from that of A-T patients, whereas the other two AMC patients demonstrated a normal response (Fig. 3).

These results suggest that: 1) the two diseases do not share additional recognizable features in addition to ataxia; 2) VI-3 is most probably affected by both disorders, whereas VI-4 and VI-14 have only AMC. The latter assumption was further tested by performing linkage analysis in the family, using DNA markers from the re-

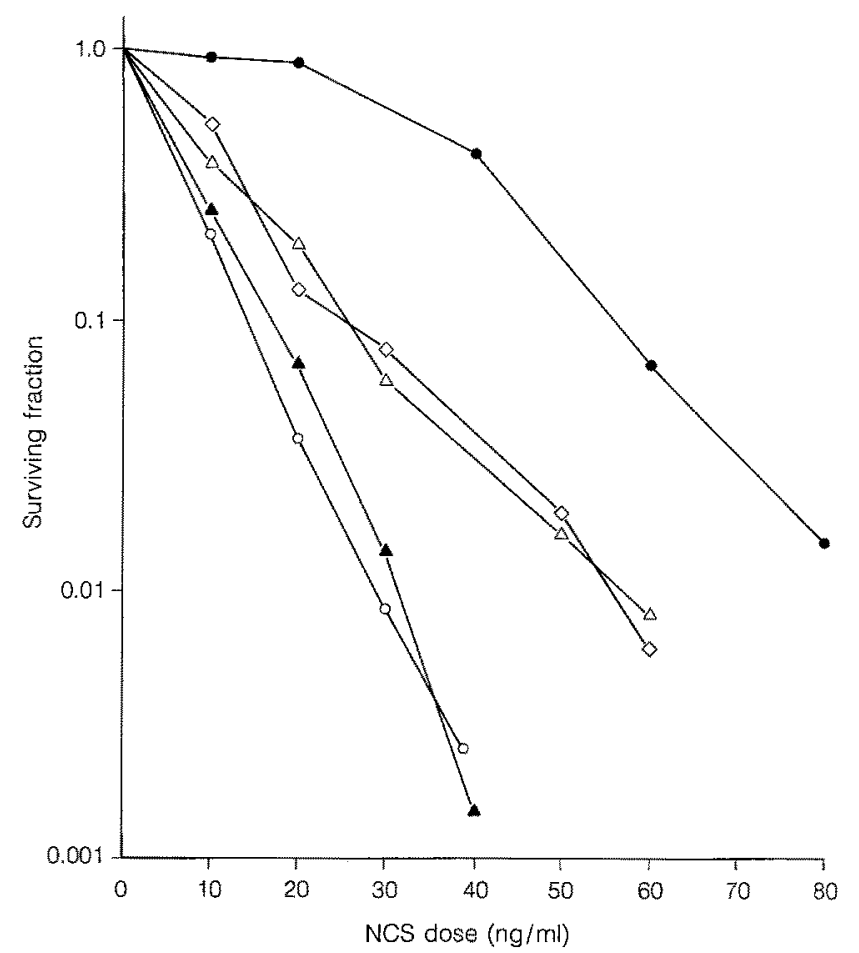

Fig. 2. Survival curves of fibroblast cell lines following treatment with various doses of NCS. Normal control; the other symbols denote members of family ISAT9: VI-2 (A), VI-3 (O), VI-4 (口), and VI-14 $(\triangle)$ 


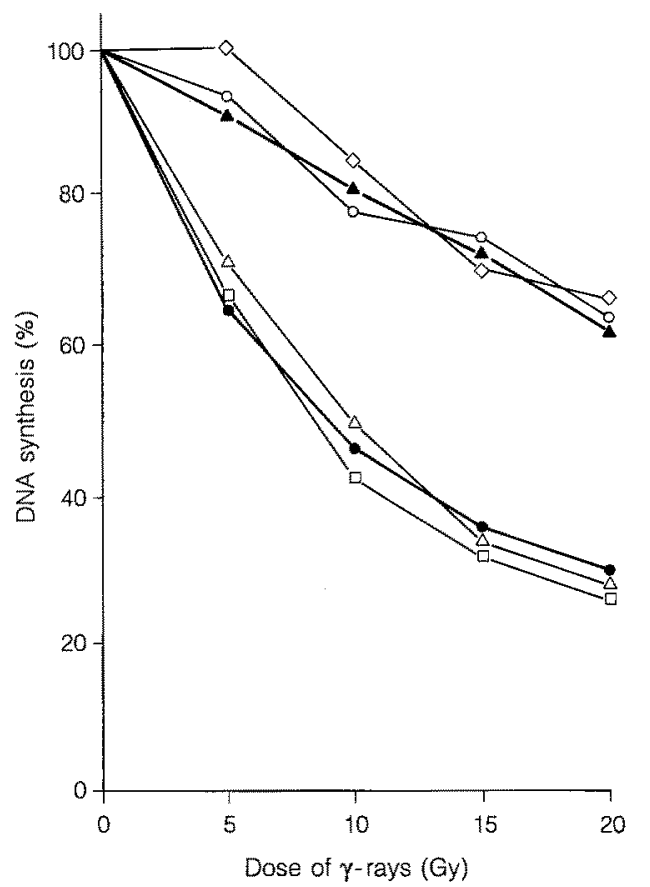

Fig. 3. Inhibition of DNA synthesis by increasing doses of $X$-irradiation in fibroblast cell lines. A AT5LA, an A-T (group A) cell line; CR70, a normal control; other symbols denote members of family ISAT9: VI-2 $(0)$, VI-3 $(\diamond)$, VI-4 $(\triangle)$ and VI- $14(\square)$

Table 4. Lod scores between A-T and 11q23 loci in family ISAT9 obtained for different genotypic assignments

\begin{tabular}{|c|c|c|c|c|c|c|}
\hline \multirow{3}{*}{$\begin{array}{l}\text { Marker } \\
\text { loci }\end{array}$} & \multicolumn{6}{|c|}{ Affected individuals in generation VI } \\
\hline & \multicolumn{2}{|c|}{$\begin{array}{l}2,5,6,8 \\
10,11\end{array}$} & \multicolumn{2}{|c|}{$\begin{array}{l}2,3,5,6,8 \\
10,11\end{array}$} & \multicolumn{2}{|c|}{$\begin{array}{l}2,3,4,5,6 \\
8,10,11,14\end{array}$} \\
\hline & $\theta$ & $Z$ & $\theta$ & $Z$ & $\theta$ & $Z$ \\
\hline STMY & 0.13 & 1.942 & 0.061 & 3.011 & 0.27 & 0.792 \\
\hline D11S84 & 0.5 & 0 & 0.022 & 0.426 & 0.5 & 0 \\
\hline D11S351 & $10^{-6}$ & 0.595 & $10^{-6}$ & 1.072 & 0.5 & 0 \\
\hline D11S29 & 0.14 & 0.824 & 0.11 & 1.185 & 0.24 & 0.574 \\
\hline CD3G & 0.22 & 0.573 & 0.18 & 0.756 & 0.23 & 0.543 \\
\hline D11S424 & 0.116 & 0.603 & $10^{-6}$ & 2.140 & 0.5 & 0 \\
\hline
\end{tabular}

gion 11q23. Initial analysis was performed with only A-T patients being considered as affected (Table 4 , right column). The lod score obtained with the marker STMY was suggestive of linkage. Lod scores were then calculated for two additional genotypic models: 1) A-T patients plus VI-3 are affected; 2) all the patients, with either A-T or AMC, are affected. With 6 markers from the $11 \mathrm{q} 23$ region, the highest lod scores for the family were obtained when A-T patients plus VI-3 were considered as being affected (Table 4 , middle column). The addition of VI-4 and VI-14, or the elimination of VI-3, reduced the lod scores and increased the genetic distance between the disease locus and each marker (Table 4). The lod scores obtained with the marker STMY for the second model was significant $(>3.0)$. Taken together, these results indicate that, in this family, as in European and American A-T families, the A-T locus is located at $11 \mathrm{q} 23$, and AMC is not linked to A-T. Individual VI-3 is apparently affected by both diseases, whereas VI-4 and VI-14 are affected with AMC alone, and are probably also A-T carriers.

\section{Linkage analysis with 11q23 markers}

Table 5 presents lod scores between A-T and various 11q23 markers for each family separately, and cumulative values for the 3 Arab families known to be of group A. The results are in agreement with previous data obtained with group A families in Turkey and USA (Gatti et al. 1988; Sanal et al. 1990). Significant cumulative lod scores were obtained with the loci STMY, D11S132, D11S144, D11S351 and D11S424, in the Arab families. No recombination events were noticed between A-T and the latter four markers. D11S132, D11S144 and D11S351 did, however, recombine with the disease in the Druze family ISAT8; this might reflect a recombination event distal to $A-T$, or a different localization of the disease locus in this family.

\section{Discussion}

Three individuals in family ISAT9 had ataxia, hypotonia, microcephaly and congenital cataracts with nystagmus; mental retardation was also observed in one of these individuals. These findings resemble the Marinesco-Sjorgen syndrome (MSS), which is characterized by cerebellar ataxia, congenital cataracts and mental retardation (Sjorgen 1950; Todorov 1965). However, microcephaly is not part of MSS, and mental retardation was present in only one of the three AMC patients in family ISAT9. In view of the young age of these patients and the possibility that the disease is progressive, a longer period of follow up is required before AMC can be defined as a new clinical entity.

The occurrence, in the same family, of two autosomal recessive diseases sharing clinical characteristics raises the possibility of a physiologic or genetic relationship between the two. The variety of genetic syndromes involving different combinations of A-T features has raised some speculation regarding putative genetic loci common to these seemingly related diseases (Ziv et al. 1989). Salient features in these diseases include chromosomal instability, immunodeficiency and radiation sensitivity. However, whereas some of these entities are clearly different from A-T (Byrne et al. 1984; Maraschio et al. 1986; Maserati et al. 1988; Wegner et al. 1988), others are regarded as "variants" of A-T (Taylor et al. 1987; Ziv et al. 1989). Of particular interest are the Nijmegen Breakage syndrome (NBS), which features chromosomal instability, radiosensitivity, immunodeficiency and microcephaly (Seemanová 1990; Taalman et al. 1989), and the $\mathrm{AT}_{\mathrm{FRESNO}}$ variant, which involves all A-T characteristics together with microcephaly and mental retardation (Curry et al. 1989).

Since microcephaly appears to be a common denominator in many of these syndromes, we were intrigued by 
Table 5. Lod scores between A-T and 11q23 loci in various A-T families ${ }^{\text {a }}$

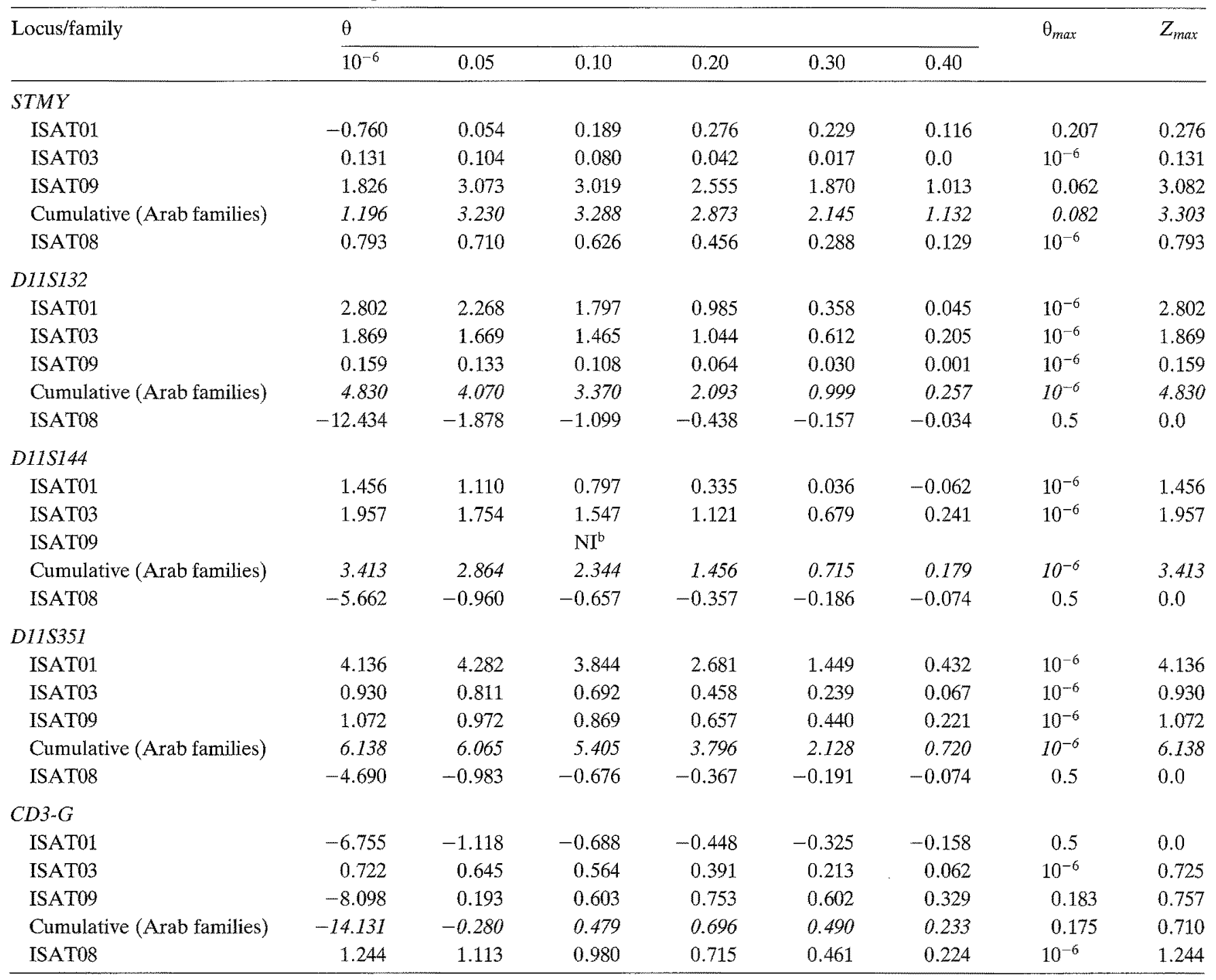

${ }^{\mathrm{a}}$ For family ISAT9 the given values of $\theta$ and $Z$ were calculated considering VI $-2, \mathrm{VI}-3, \mathrm{VI}-5, \mathrm{VI}-6, \mathrm{VI}-8, \mathrm{VI}-10$, and VI-11 as affected ${ }^{b}$ NI, Not informative

its appearance in our AMC patients. However, our search for similarities between $\mathrm{AMC}$ and $\mathrm{A}-\mathrm{T}$ in addition to ataxia revealed no further resemblance between the two diseases at either the clinical or the cellular level. It should also be noted that cataract is not characteristic of any of the above diseases. Further evidence for this differentiation was obtained from linkage analysis, which indicated that the two diseases are clearly not linked genetically. The occurrence of these two autosomal recessive diseases in family ISAT9 is thus fortuitous, and probably reflects the high degree of inbreeding in this pedigree.

The differentiation of AMC from A-T, and the identification of VI-3 as being affected by both, enabled us to extract, from family ISAT9, the maximal amount of linkage information with regard to A-T. The results in the 3 Arab A-T (group A) families corroborate those that were obtained in other ethnic groups, and that localized the ATA gene to a 4 centiMorgan (male-specif- ic) interval at $11 \mathrm{q} 23$, flanked on the centromeric side by STMY/D11S35/D11S385, and on the distal side by NCAM/DRD2 (Gatti et al. 1988; McConville et al. 1990a,b; Sanal et al. 1990). Evidence supporting the localization of the A-T gene of family ISAT8 alone to chromosome 11q23 could not be obtained; this awaits new markers more tightly linked to A-T, and the eventual isolation of the A-T genes. Until this question is resolved, our data indicate the need for caution in applying the presently available $11 \mathrm{q} 23$ markers for diagnostic purposes in $\mathrm{A}-\mathrm{T}$ families not assigned to specific complementation groups.

Acknowledgements. We are indebted to the investigators who contributed molecular probes for this study, and to the patients and their families for their patience and cooperation. This study was supported by the Ataxia-Telangiectasia Medical Research Foun dation, The Israel Association Against Cancer and the USA Department of Energy. G.R. is a Fellow of the Israel Association Against Cancer. 


\section{References}

Arlett CF, Priestley A (1985) An assessment of the radiosensitivity of ataxia-telangiectasia heterozygotes. In: Gatti RA, Swift M (eds) Ataxia-telangiectasia: genetics neuropathology and immunology of a degenerative disease of childhood. Liss, New York, pp 101-109

Boder E (1985) Ataxia-telangiectasia; an overwiew. In: Gatti RA, Swift $M$ (eds) Ataxia-telangiectasia: genetics neuropathology and immunology of a degenerative disease of childhood. Liss, New York, pp 1-63

Byrne E, Hallpike JF, Manson JI, Sutherland GR, Thong YH (1984) Ataxia-without-telangiectasia. Progressive multisystem degeneration with IgE deficiency and chromosomal instability. J Neurol Sci 66:307-317

Carlson M, Nakamura $\mathrm{Y}$, Krapcho $\mathrm{K}$, Payson $\mathrm{R}$, O'Connell P, Leppert M, Lathrop GM, et al. (1988) Isolation and mapping of a polymorphic DNA sequence MCT128.1 on chromosome 11 [D11S285]. Nucleic Acids Res 16:378

Charmley P, Wei S, Sanal O, Malhotra U, Concannon P, Terhorst C, Gatti RA (1989) Human T-cell receptor CD3-gamma (CD3G)/MspI DNA polymorphism. Nucleic Acids Res 17:2373

Cohen MM, Levy HP (1989) Chromosome instability syndromes. Adv Hum Genet 18:43-147

Cohen MM, Hirschhorn K, Frosch WA (1967) In vivo and in vitro chromosome damage induced by LSD 25 . N Engl J Med 277: $1043-1049$

Curry CJR, Tsai J, Hutchinson HT, Jaspers NGJ, Wara D, Gatti

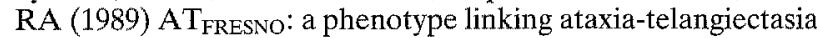
with the Nijmegen breakage syndrome. Am J Hum Genet 45: $270-275$

Donis-Keller H, Green P, Helms C, Cartinhour S, Weiffenbach B, et al. (1987) A genetic linkage map of the human genome. Cell 51:319-337

Feinberg AP, Vogelstein B (1983) A technique for radiolabeling DNA restriction endonuclease fragments to high specific activity. Anal Biochem 132:6-13

Fiorilli M, Antonelli A, Russo G, Crescenzi M, Carbonari M, Petrinelli P (1985) Variant of ataxia telangiectasia with low-level radiosensitivity. Hum Genet 70:274-277

Gatti RA, Berkel I, Boder E, Braedt G, Charmley P, Concannon P, Ersoy F, Foroud T, Jaspers NGJ, Lange K, Lathrop GM, Leppert M, Nakamura Y, O'Connell P, Paterson M, Salser W, Sanal O, Silver J, Sparkes RS, Susi E, Weeks D, Wei S, White $R$, Yoder F (1988) Localization of an ataxia-telangiectasia gene to chromosome 11q22-23. Nature 336:577-580

Jaspers NGJ, Gatti RA, Baan C, Linssen PCML, Bootsma D (1988a) Genetic complementation analysis of ataxia telangiectasia and Nijmegen breakage syndrome: a survey of $50 \mathrm{pa}-$ tients. Cytogenet Cell Genet 49:259-263

Jaspers NGJ, Taalman RDFM, Baan C (1988b) Patients with an inherited syndrome characterized by immunodeficiency, microcephaly, and chromosomal instability: genetic relationship to ataxia telangiectasia. Am J Hum Genet 42:66-73

Julier C, Nakamura Y, Lathrop M, O'Connell P, Leppert M, Litt M, Mohandas T, Lalouel J-M, White R (1990) Detailed map of the long arm of chromosome 11. Genomics 7:335-345

Klinger HP (1987) Rapid processing of primary embryonic tissue for chromosome pattern analysis. Cytogenet Cell Genet 11: 424-435

Lange K, Boehnke M (1983) Extensions to pedigree analysis. V. Optimal calculation of Mendelian likelihoods. Hum Hered 33: 291-301

Lange K, Goradia TM (1987) An algorithm for automatic genotype elimination. Am J Hum Genet 40:250-256

Lange K, Boehnke M, Weeks D (1988) Programs for pedigree analysis: MENDEL, FISHER and dGENE. Genet Epidemiol $5: 471-482$

Maraschio P, Peretti D, Lambiase S, Lo Curto F, Caufin D, Gargantini L, Minoli L, Zuffardi $O$ (1986) A new chromosome instability disorder. Clin Genet 30:353-365
Maserati E, Ottolini A, Veggiotti P, Lanzi G, Pasquali F (1988) Ataxia-without-telangiectasia in two sisters with rearrangements of chromosomes 7 and 14. Clin Genet 34:283-287

Maslem C, Jones C, Glaser T, Sheehy R, Magenis RE, Kellogg J, Litt M (1987) Seven polymorphic loci mapping to human chromosomal region 11q22-qter. (9th International Workshop on Human Gene Mapping) Cytogenet Cell Genet 46-656

McConville CM, Woods GC, Farrall M, Metcalf JA, Taylor AMR (1990a) Analysis of 7 polymorphic markers at chromosome $11 \mathrm{q} 22-23$ in 35 ataxia telangiectasia families; further evidence of linkage. Hum Genet $85: 215-220$

McConville CM, Formstone CJ, Hernandez D, Thick J, Taylor AMR (1990b) Fine mapping of the chromosome 11q22-23 region using PFGE, linkage and haplotype analysis; localization of the gene for ataxia telangiectasia to a $5 \mathrm{cM}$ region flanked by NCAM/DRD2 and STMY/CJ52.75, $\varnothing 2.22$. Nucleic Acids Res $18: 4335-4343$

McKinnon PJ (1987) Ataxia-telangiectasia: an inherited disorder of ionizing radiation sensitivity in man. Hum Genet $75: 197$ 208

Morrell D, Cromartie E, Swift M (1986) Mortality and cancer incidence in 263 patients with ataxia-telangiectasia. J Natl Cancer Inst $77: 89-92$

Paterson MC, MacFarlane SJ, Gentner N, Smith BP (1985) Cellular hypersensitivity to chronic gamma-radiation in cultured fibroblasts from ataxia-telangiectasia heterozygotes. In: Gatti RA, Swift M (eds) Ataxia-telangiectasia: genetics neuropathology and immunology of a degenerative disease of childhood. Liss, New York, pp 73-87

Sakai K, Kanda N, Shiloh Y, Donlon T, Shipley J, Dryja T, Latt S (1985) Molecular and cytological analysis of DNA amplification in retinoblastoma. Cancer Genet Cytogenet 17:95-112

Sambrook J, Fritsch EF, Maniatis T (1989) Molecular cloning: a laboratory manual. Cold Spring Harbor Laboratory, Cold Spring Harbor, NY

Sanal O, Wei S, Foroud T, Malhotra U, Concannon P, Charmley P, Lange K, Gatti RA (1990) Further mapping of an ataxiatelangiectasia locus to the chromosome 11 q23 region. Am J Hum Genet 47:860-866

Schwarzacher HG, Wolf U (1974) Methods in human cytogenetics. Springer, Berlin Heidelberg New York

Seemanová E (1990) An increased risk for malignant neoplasms in heterozygotes for a syndrome of microcephaly, normal intelligence, growth retardation, remarkable facies, immunodeficiency and chromosomal instability. Mutat Res 238:321-324

Shiloh Y, Tabor E, Becker Y (1982) Cellular hypersensitivity to neocarzinostatin in ataxia-telangiectasia skin fibroblasts. Cancer Res 42:2247-2249

Shiloh Y, Tabor E, Becker Y (1983) Abnormal response of ataxiatelangiectasia cells to agents that break the deoxyribose moiety of DNA via a targeted free radical mechanism. Carcinogenesis $4: 1317-1322$

Shiloh Y, Tabor E, Becker Y (1985) In-vitro phenotype of A-T fibroblast strains: clues to the nature of the "A-T DNA lesion" and the molecular defect in A-T. In: Gatti RA, Swift M (eds) Ataxia-telangiectasia: genetics neuropathology and immunology of a degenerative disease of childhood. Liss, New York, pp 111-121

Sjorgen $\mathrm{T}(1950)$ Hereditary congenital spinocerebellar ataxia accompanied by congenital cataract and oligophrenia. Confin Neurol 10:293-308

Southern E (1975) Detection of specific sequences among DNA fragments separated by gel electrophoresis. J Mol Biol 98:497500

Spector BD, Fillipovich AH, Perry GS, Kersey JH (1982) Epidemiology of cancer in ataxia-telangiectasia. In: Bridges BA, Harnden DG (eds) Ataxia-telangiectasia - a cellular and molecular link between cancer, neuropathology and immune deficiency. Wiley, Chichester, pp 103-127

Spurr NK, Gough AC, Gosden J, Rout D, Porteous DJ, Van Heyningen V, Docherty AJ (1988) Restriction fragment length 
polymorphism analysis and assignment of the metalloproteinases stromelysin and collagenase to the long arm of chromosome 11. Genomics 2:229-232

Swift M (1985) Genetics and epidemiology of ataxia-telangiectasia. In: Gatti RA, Swift M (eds) Ataxia-telangiectasia: genetics neuropathology and immunology of a degenerative disease of childhood. Liss, New York, pp 133-146

Swift M, Morrell D, Cromartie E, Chamberlain AR, Skolnick MH, Bishop DT (1986) The incidence and gene frequency of ataxia-telangiectasia in the United States. Am J Hum Genet $39: 573-583$

Taalman RDFM, Hustinx TWJ, Weemaes CMR, Seemanová E, Schmidt A, Passarge E, Scheres JMJC (1989) Further delineation of the Nijmegen breakage syndrome. Am J Med Genet $32: 425-431$

Taylor AMR (1982) Cytogenetics in ataxia-telangiectasia. In: Bridges BA, Harnden DG (eds) Ataxia-telangiectasia - a cellular and molecular link between cancer, neuropathology and immune deficiency. Wiley, Chichester, pp 53-81

Taylor AMR, Flude E, Laher B, Stacy M, McKay E, Watt J, Green SH, Harding AE (1987) Variant forms of ataxia telangiectasia. J Med Genet 24:669-677
Todorov AB (1965) Le syndrome de Marinesco-Sjorgen: première ètude anatomo-clinique. J Genet Hum 14:197-233

Warnich L, Kotze MJ, Retief AE, Dietzch E, Fox MF, Kotze GM, Nicholson DL, Retief E, Oosthuizen CJJ (1986) An anonymous human single copy genomic clone, D11S29 (L7) at 11q23 identifies a moderately frequent RFLP. Nucleic Acids Res $14: 1920$

Wegner RD, Metzger M, Hanefeld F, Jaspers NGJ, Baan C, Magdorf K, Kunze J, Sperling K (1988) A new chromosomal instability disorder confirmed by complementation studies. Clin Genet 33:20-32

Ziv Y, Amiel A, Jaspers NGJ, Berkel AI, Shiloh Y (1989) Ataxia telangiectasia: a variant with altered in vitro phenotype of fibroblast cells. Mutat Res 210:211-219

Ziv Y, Rotman G, Frydman M, Foroud T, Gatti RA, Shiloh Y (1991) The ATC (ataxia-telangiectasia complementation group C) locus localizes to 11q22-q23. Genomics 9:373-375 